\title{
Regulation of Neurotrophin Receptor Expression by Retinoic Acid in Mouse Sympathetic Neuroblasts
}

\author{
Sean Wyatt, ${ }^{1}$ Rosa Andres, ${ }^{1}$ Hermann Rohrer, ${ }^{2}$ and Alun M. Davies ${ }^{1}$ \\ ${ }_{1}^{1}$ School of Biological and Medical Sciences, Bute Medical Buildings, University of St. Andrews, St. Andrews, Fife KY16 \\ 9AJ, Scotland, and 2Max-Planck-Institut für Hirnforschung, Abteilung Neurochemie, D-60528 Frankfurt/Main, Germany
}

\begin{abstract}
We have studied the effect of retinoic acid on the expression of the neurotrophin receptors trkA, trkC, and $\mathrm{p} 75$ by neuroblasts and neurons at different axial levels along the embryonic mouse paravertebral sympathetic chain. In dissociated cultures of sympathetic neuroblasts, retinoic acid inhibited the developmental increase in trkA mRNA expression and the developmental decrease in trkC mRNA expression that normally occurs in these cells but did not affect p75 mRNA expression. At higher concentrations, retinoic acid also increased the proliferation of sympathetic neuroblasts. After sympathetic neuroblasts be-
\end{abstract}

came postmitotic, retinoic acid no longer affected receptor expression. Studies with retinoic acid receptor agonists and antagonists indicated that the effects of retinoic acid on neurotrophin receptor expression were mediated mainly by $\alpha$ retinoic acid receptors, not $\beta$ or $\gamma$ receptors. The observation that $\alpha$-antagonists increased trkA mRNA expression in intact sympathetic ganglion explants suggests that endogenous retinoic acid is a physiological regulator of trkA receptor expression.

Key words: retinoic acid; Trk receptor; p75 receptor; neurotrophin; sympathetic neuron; sympathetic neuroblast
Neurons of the developing peripheral nervous system depend for survival on one or more neurotrophins (Davies, 1994; Lewin and Barde, 1996). The trophic effects of these proteins are mediated by the Trk family of receptor tyrosine kinases (Barbacid, 1994; Bothwell, 1995). TrkA is a receptor for nerve growth factor (NGF), TrkB is a receptor for brain-derived neurotrophic factor (BDNF) and neurotrophin-4 (NT4), and TrkC is a receptor for neurotrophin-3 (NT3). Neurotrophins also bind to another transmembrane glycoprotein, p75 (Bothwell, 1995), which modulates the response of cells to neurotrophins (Davies et al., 1993; Lee et al., 1994; Ryden et al., 1995) and in certain cells mediates a cytotoxic response (Rabizadeh et al., 1993; Barrett and Bartlett, 1994; Casaccia-Bonnefil et al., 1996; Frade et al., 1996; Van der Zee et al., 1996; Bamji et al., 1998; Davey and Davies, 1998).

The response of neurons to neurotrophins changes during development. Some neurons are not dependent on neurotrophins for survival during the earliest stages of axonal outgrowth (Davies and Lumsden, 1984; Coughlin and Collins, 1985; Ernsberger and Rohrer, 1988; Ernsberger et al., 1989; Vogel and Davies, 1991), and some neurons switch their survival requirements from one neurotrophin to another during development (Buchman and Davies, 1993; Paul and Davies, 1995; Farinas et al., 1996; Piñón et al., 1996; Wilkinson et al., 1996). The onset of the survival responses of developing neurons to NGF and BDNF is correlated with marked increases in the expression of the corresponding Trk receptors (Wyatt and Davies, 1993, 1995; Ninkina et al., 1996;

\footnotetext{
Received July 17, 1998; revised Nov. 16, 1998; accepted Nov. 20, 1998.

We thank Ruth Edgar for technical assistance, Dr. G. Burton (Genentech, San Francisco, CA) for the purified recombinant NGF and NT3, Dr. M. Klaus (Novartis, Basel, Switzerland) for the retinoids, and Dr. A. von Holst for critical comments on this manuscript. This work was supported by Grant 038020/Z/93 from the Wellcome Trust to A.M.D. and Grant 10-1146-Ro2 from the Deutsche Krebshilfe to H.R.

Correspondence should be addressed to Dr. Alun Davies, School of Biological and Medical Sciences, Bute Medical Buildings, University of St. Andrews, St. Andrews, Fife K Y16 9AJ, Scotland.

Copyright (C) 1999 Society for Neuroscience $\quad 0270-6474 / 99 / 191062-10 \$ 05.00 / 0$
}

Robinson et al., 1996; Holst et al., 1997). However, little is known about how Trk expression is regulated.

The timing of neurotrophin responsiveness and receptor expression has been studied extensively in paravertebral sympathetic ganglia. These ganglia initially contain dividing cells that exhibit various neuronal features (Cohen, 1974; Rothman et al., 1978, 1980; Anderson and Axel, 1986; Rohrer and Thoenen, 1987; DiCicco-Bloom and Black, 1988; DiCicco-Bloom et al., 1990). These proliferating sympathetic neuroblasts survive independently of neurotrophins (Ernsberger et al., 1989; Wyatt and Davies, 1995) but depend in part on hepatocyte growth factor for survival (Maina et al., 1998). Postmitotic sympathetic neurons become dependent on NGF for survival (Johnson et al., 1980; Levi-Montalcini, 1987; Crowley et al., 1994; Smeyne et al., 1994). The onset of NGF dependence is correlated with a marked increase in trkA expression (Wyatt and Davies, 1995; Holst et al., 1997). The sensitivity of sympathetic neurons to NGF is enhanced later in embryonic development by p75 (Lee et al., 1994), whose expression increases markedly at this time and approaches that of trkA postnatally (Wyatt and Davies, 1995; Horton et al., 1997). Although sympathetic neuroblasts and early sympathetic neurons express high levels of trkC mRNA and survive longer in the presence of NT3 in vitro (Birren et al., 1993; Dechant et al., 1993; DiCicco-Bloom et al., 1993), detailed analysis of $n t 3^{-/-}$ mice has shown that endogenous NT3 is not required for sympathetic neuroblast survival in vivo but that some sympathetic neurons acquire dependence on NT3 late in embryonic development after becoming dependent on NGF for survival (Wyatt et al., 1997).

In vitro studies of sympathetic neuroblasts cultured from the lumbar paravertebral sympathetic chain of chicken embryos have shown that retinoic acid induces trkA expression and the onset of NGF dependence (Rodriguez-Tebar and Rohrer, 1991; Holst et al., 1995, 1997). In contrast, our present studies of sympathetic neurons cultured from three different levels of the paravertebral sympathetic chain of mouse embryos demonstrate that retinoic 
acid has the opposite effect. Retinoic acid prevents the normal developmental increase in trkA mRNA expression in sympathetic neuroblasts and has the reciprocal effect on trkC expression. Our finding that these effects of retinoic acid are mediated at least in part by $\alpha$ retinoic acid receptors (RARs- $\alpha$ ) and that $\mathrm{RAR}-\alpha$ antagonists accelerate trkA mRNA expression in explant cultures suggests that endogenous retinoic acid plays a role in regulating trkA receptor expression during development.

\section{MATERIALS AND METHODS}

Neuron cultures. Mouse embryos were obtained from overnight matings of CD1 mice. Tungsten needles were used to dissect superior cervical sympathetic ganglia (SCG), thoracic paravertebral sympathetic ganglia, and lumbar paravertebral sympathetic ganglia from embryos of 13.5, 14.5 , and $15.5 \mathrm{~d}$ gestation (morning of vaginal plug was considered to be $0.5 \mathrm{~d}$ of gestation). The ganglia were trypsinized, dissociated, and plated at low density in polyornithine/laminin-coated 35-mm-diameter plastic tissue culture dishes (500-2000 neurons per dish) containing defined medium as described previously (Wyatt and Davies, 1993). The cultures were incubated at $37^{\circ} \mathrm{C}$ in a $5 \% \mathrm{CO}_{2}$ incubator for 24 or $48 \mathrm{hr}$. The number of attached neuroblasts or neurons within a $12 \times 12 \mathrm{~mm}$ square in the center of each dish was counted $6 \mathrm{hr}$ after plating. The number of surviving neuroblasts or neurons in the same area was counted at intervals and expressed as a percentage of the initial number of neurons counted. In each experiment, triplicate cultures were set up for all conditions. Explant cultures were grown in four-well dishes (Nunclon) with two explants per well in $0.5 \mathrm{ml}$ medium. Unless stated otherwise, all cultures received $5 \mathrm{ng} / \mathrm{ml}$ NGF (gift of John Winslow and Gene Burton, Genentech, San Francisco, CA).

Retinoids were dissolved in DMSO at concentrations of $10-50 \mathrm{~mm}$ and subsequently diluted in medium to the concentrations indicated. The RAR- $\alpha$-selective agonists Ro 40-6055 and Ro 40-6973 (Am-80), the RAR- $\beta$-selective agonist Ro 19-0645, the RAR- $\gamma$-selective agonist Ro 44-7081, and the RAR- $\alpha$-selective antagonist Ro 41-5253 were generously provided by Dr. M. Klaus (Novartis, Basel).

Quantification of neurotrophin receptor $m R N A$ levels. A quantitative, competitive RT-PCR technique (Wyatt and Davies, 1993) was used to measure the levels of trkA, trkC, p75, and glyceraldehyde phosphate dehydrogenase (GAPDH) mRNAs in total RNA extracted from cultures. The RT and PCR reactions were calibrated by the inclusion of known amounts of cRNA competitor templates for each of the mRNAs in the $\mathrm{RT}$ reaction. The cRNA competitor templates were synthesized in vitro from cDNA competitor constructs. The details of the primers, control templates, reaction conditions, and quantification are provided elsewhere (Wyatt and Davies, 1993; Wyatt et al., 1997).

Neuroblast proliferation. Neuroblast proliferation was studied by determining the number of neuroblasts that incorporated bromodeoxyuridine (BrdU) into their nuclei using immunocytochemistry. Cells were plated in the $11 \mathrm{~mm}$ wells of four-well dishes (Greiner), BrdU was added after a $3 \mathrm{hr}$ incubation, and the cultures were fixed after a further $12 \mathrm{hr}$ incubation in methanol $\left(-20^{\circ} \mathrm{C}\right.$ for $\left.15 \mathrm{~min}\right)$. The cells were stained for nuclear BrdU incorporation following the manufacture's instructions (Cell Proliferation kit, Amersham, Arlington Heights, IL). The number of BrdU-positive cells is expressed as a percentage of total cell number. The great majority of labeled cells exhibited the typical morphology of sympathetic neuroblasts (Maina et al., 1998); the very small number of fibroblast-like cells in these cultures was not included in the analysis.

\section{RESULTS}

\section{Retinoic acid reduces trkA mRNA expression in sympathetic neuroblasts}

Competitive RT-PCR was used to measure the level of trkA mRNA in low-density dissociated cultures established from the SCG, thoracic ganglia, and lumbar ganglia of the embryonic mouse paravertebral sympathetic chain at intervals during its early development. Ganglia from different axial levels were analyzed because there is evidence that they are derived from distinct lineages and differ in their dependence on survival factors (Durbec et al., 1996; Moore et al., 1996). Unless stated otherwise, NGF was added to all cultures to sustain the survival of postmi- totic sympathetic neurons. Although very few NGF-dependent postmitotic neurons were present in embryonic day (E) 13.5 cultures, the numbers of these neurons increased markedly by E15.5 (Wyatt and Davies, 1995). The level of trkA mRNA increased from E13.5 to E15.5 in cultures without added retinoic acid (Fig. 1). At each age, the level of trkA mRNA was highest in cervical cultures and lowest in lumbar cultures (Fig. 1), reflecting the rostrocaudal sequence of neuronal development in the sympathetic chain.

At E13.5, when the majority of cells in the chain are proliferating sympathetic neuroblasts, retinoic acid caused a marked, dose-dependent decrease in trkA mRNA expression (Fig. $1 A$ ). After $48 \mathrm{hr}$, the level of trkA mRNA was significantly lower in cultures supplemented with $10^{-10} \mathrm{M}$ retinoic acid compared with cultures containing NGF alone ( $p<0.05$, for all regions, $t$ tests), and progressively greater reductions were observed in cultures containing higher concentrations of retinoic acid. At the highest concentration used $\left(10^{-6} \mathrm{M}\right)$, the level of trkA mRNA was $\sim 95 \%$ lower than in cultures not containing retinoic acid (Fig. 1D). Although the data reported in Figure 1 are taken from NGFsupplemented cultures, very similar results were obtained from E13.5 cultures grown without NGF (data not shown).

At E14.5, when the earliest sympathetic neurons in the chain become dependent on NGF for survival but a large number of proliferating sympathetic neuroblasts still remain (Wyatt and Davies, 1995), retinoic acid also caused a large decrease in trkA mRNA expression (Fig. 1B). However, the decrease was not as pronounced as that observed at E13.5. By $48 \mathrm{hr}$, the percentage reduction in the presence of $10^{-6} \mathrm{M}$ retinoic acid ranged from $94 \%$ for lumbar cultures to $60 \%$ for SCG cultures, with a mean decrease of $\sim 75 \%$ (Fig. 1D).

At E15.5, when the majority of cells in the chain are postmitotic sympathetic neurons that have become dependent on NGF for survival but a small number of proliferating neuroblasts remain (Wyatt and Davies, 1995), retinoic acid had a negligible effect on trkA mRNA expression (Fig. 1C). The mean percentage decrease in the presence of $10^{-6} \mathrm{M}$ retinoic acid was only $23 \%$ (Fig. $1 D$ ); however, this decrease was statistically significant $(p<0.001, t$ test). The age-related changes in the effect of retinoic on trkA expression is summarized in Figure $1 D$.

To exclude the possibility that the reduction in trkA mRNA expression in the presence of retinoic acid was caused by a toxic effect of this reagent, we compared the number of neurons surviving in cultures containing NGF plus different concentrations of retinoic acid with the number in cultures containing NGF alone. In each set of cultures after $48 \mathrm{hr}$ incubation, there was no significant difference in percentage survival in cultures containing NGF alone and cultures containing NGF plus retinoic acid at each of the concentrations used (data not shown). The percent survival in E13.5 cervical and thoracic cultures ranged between 85 and $100 \%$ and was lower in E13.5 lumbar cultures (between 48 and 65\%). The percentage survival in E14.5 cultures of all regions ranged from 42 to $77 \%$ and in E15.5 cultures ranged from 64 to $77 \%$. In the absence of NGF, the percentage survival fell from a mean of $78 \%$ in E13.5 cultures to 24 and $4 \%$ in E14.5 and E15.5 cultures, respectively.

To ascertain how the expression of trkA mRNA changes with time in culture in the presence and absence of retinoic acid, the level of trkA mRNA was measured at intervals from the time of plating to $48 \mathrm{hr}$ incubation. In E13.5 cultures, a small decrease in trkA mRNA expression was consistently observed under both conditions during the first $9 \mathrm{hr}$ in vitro (Fig. 2). After this time, the 


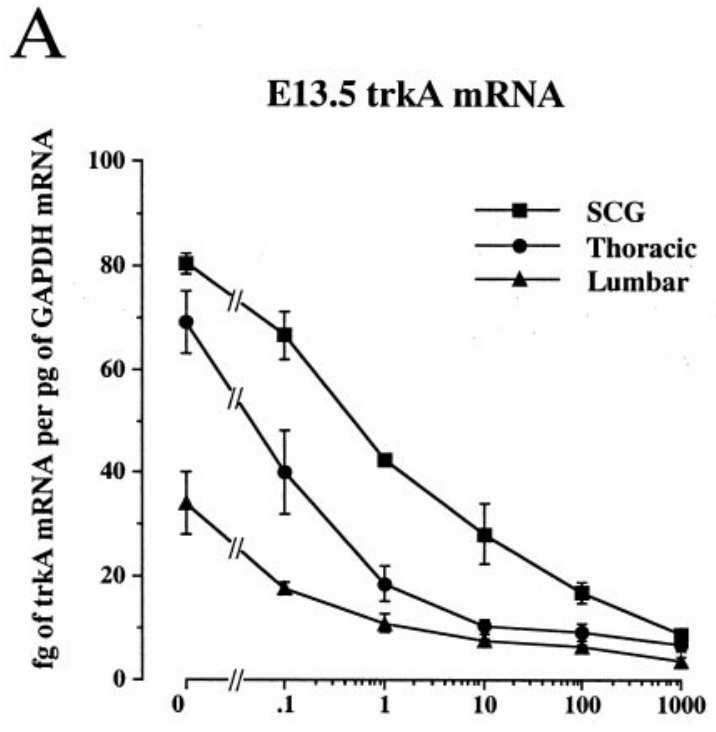

Retinoic acid concentration (nM)
B

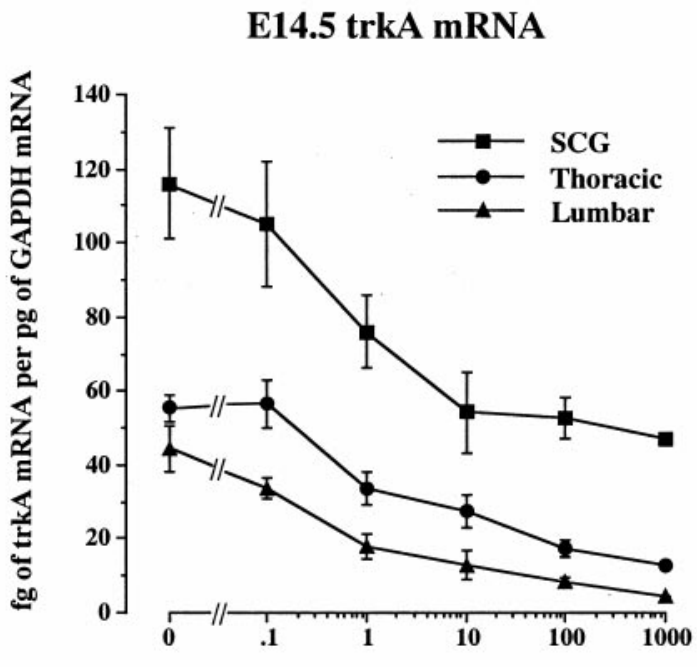

Retinoic acid concentration (nM)

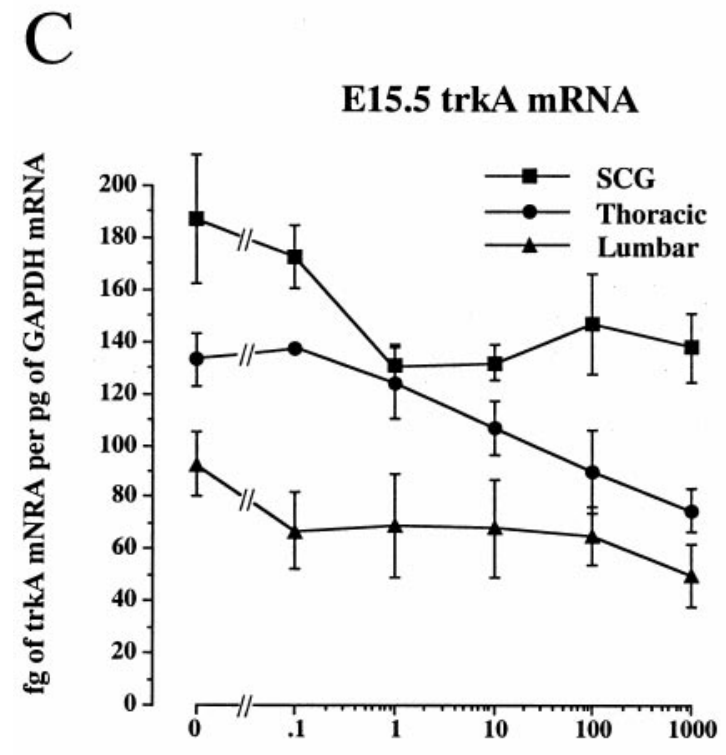

Retinoic acid concentration (nM)
$\mathrm{D}$

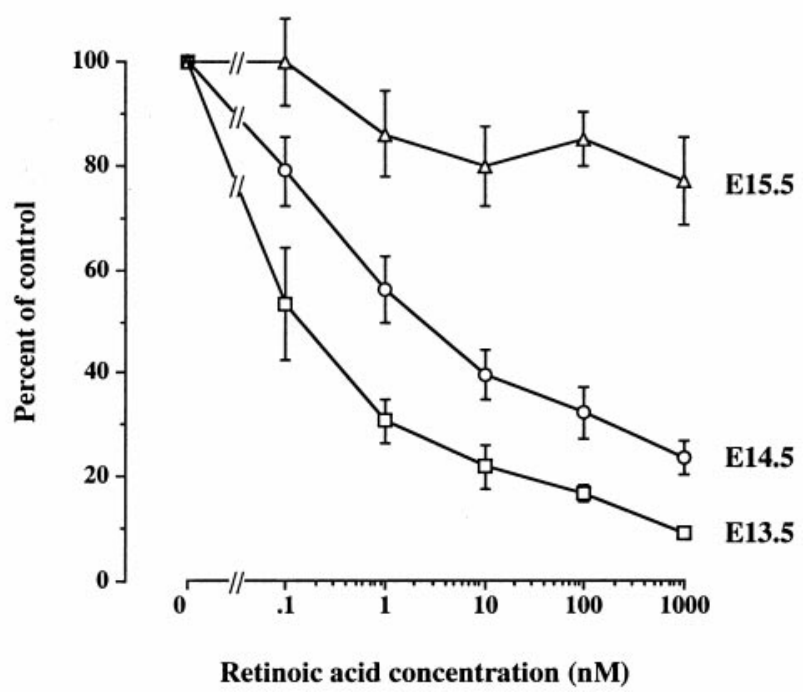

Figure 1. Graphs of the levels of trkA mRNA (relative to the level of the mRNA encoding the housekeeping protein GAPDH) in dissociated cultures of E13.5 $(A)$, E14.5 $(B)$, and E15.5 $(C)$ SCG and thoracic and lumbar paravertebral sympathetic ganglia after $48 \mathrm{hr}$ in culture with $5 \mathrm{ng} / \mathrm{ml} \mathrm{NGF}$ alone and NGF plus retinoic acid over a range of concentrations. The mean and SE of data from three to eight separate culture experiments are combined for each data point. $D$ summarizes the changes with age in the relative level of trkA mRNA in SCG, thoracic, and lumbar cultures containing different concentrations of retinoic acid expressed as a percentage of the level in cultures grown without retinoic acid (derived from the combined data shown in $A-C$ ).

level of trkA mRNA in cultures without retinoic acid increased markedly, mirroring the developmental increase in trkA mRNA expression in vivo (Wyatt and Davies, 1995), whereas in the presence of retinoic acid the level of trkA mRNA remained low. The increase in trkA mRNA expression in cultures without retinoic acid was observed both in the presence and absence of NGF (data not shown). Thus, the reduced level of trkA mRNA expression observed in sympathetic neuroblasts cultured for $48 \mathrm{hr}$ with retinoic acid is attributable to an inhibition of the developmental rise in trkA mRNA expression rather than to a further reduction in trkA mRNA expression.

\section{Retinoic acid increases trkC mRNA expression in sympathetic neuroblasts}

Alternative splicing generates transcripts that encode TrkC variants that possess or lack the intracellular tyrosine kinase domain (Lamballe et al., 1993; Tsoulfas et al., 1993; Valenzuela et al., 1993). The levels of mRNAs encoding catalytic $\left(\mathrm{TK}^{+}\right)$and non- 


\section{E13.5 SCG neuroblasts}

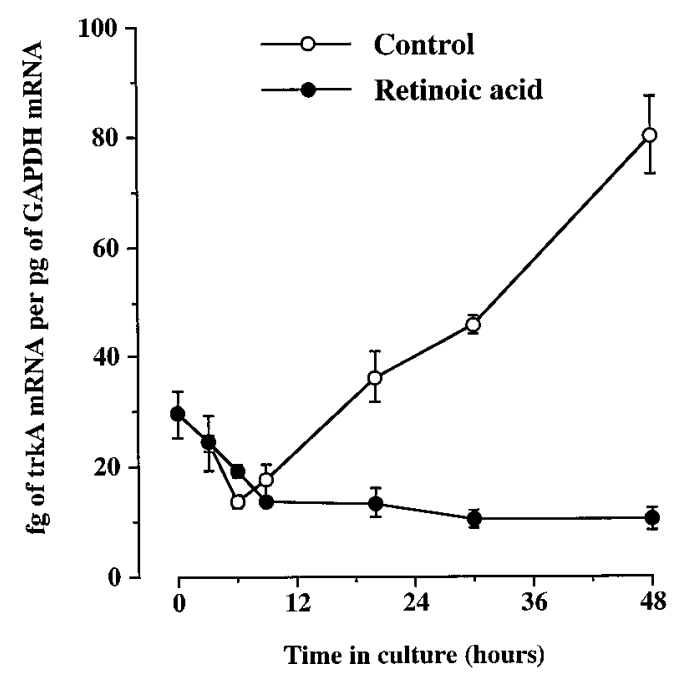

Figure 2. Graph of the level of trkA mRNA (relative to GAPDH RNA) in dissociated cultures of E13.5 SCG neuroblasts grown in culture with 5 $\mathrm{ng} / \mathrm{ml} \mathrm{NGF}$ alone (Control) and NGF plus $10^{-7} \mathrm{M}$ retinoic acid at intervals from plating to $48 \mathrm{hr}$ incubation. All cultures were supplemented with $5 \mathrm{ng} / \mathrm{ml} \mathrm{NGF}$. The mean and SE of four separate cultures are shown for each data point.

catalytic $\left(\mathrm{TK}^{-}\right)$TrkC variants were measured by competitive RT-PCR (Wyatt et al., 1997). In contrast to the repression of trkA mRNA expression by retinoic acid, the level of trkC $\mathrm{TK}^{+}$mRNA in cultures of E13.5 cervical, thoracic, and lumbar sympathetic neuroblasts was substantially elevated by retinoic acid (Fig. 3A). A dose-dependent increase in trkC $\mathrm{TK}^{+}$mRNA was observed over the $10^{-10}$ to $10^{-6} \mathrm{M}$ range, with a sixfold increase at the highest concentration (Fig. 3D). Retinoic acid also caused a marked increase in trkC $\mathrm{TK}^{+}$mRNA expression in E14.5 cultures, although the increase was not as pronounced as that observed in E13.5 cultures (Fig. 3B). By 48 hr, there was a fourfold increase in the presence of $10^{-6} \mathrm{M}$ retinoic acid (Fig. $3 D$ ). In E15.5 cultures, retinoic acid had no effect on trkC $\mathrm{TK}^{+}$mRNA expression (Fig. $3 C$ ). In addition to the age-related effects on $\operatorname{trkC} \mathrm{TK}^{+}$expres-

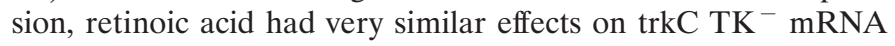
expression in these cultures (data not shown).

\section{Retinoic acid does not affect p75 mRNA expression}

In addition to studying the effect of retinoic acid on the expression of trkA and trkC transcripts in developing sympathetic neuroblasts and neurons, we used competitive RT-PCR to measure the level of p75 mRNA in the same cultures. In contrast to the marked effect of retinoic acid on the expression of trkA and trkC mRNAs in sympathetic neuroblasts, the level of p75 mRNA was very similar in the presence and absence of retinoic acid in cultures established from all axial levels of the sympathetic chain and at all ages studied (Fig. 4).

\section{RAR- $\alpha$ mediates the effects of retinoic acid on sympathetic neuroblasts}

Two families of nuclear receptors mediate the actions of retinoic acid: the RARs and the retinoid $\mathrm{X}$ receptors, each consisting of at least three members, $\alpha, \beta$, and $\gamma$ (Leid et al., 1992). To ascertain which RAR subtypes mediate the effects of retinoic acid on trkA mRNA expression, we studied the effects of RAR subtype-selective synthetic retinoid agonists (Apfel et al., 1992;
Armstrong et al., 1994). Figure 5 shows that only $\alpha$-selective retinoid agonists were effective in reducing trkA mRNA expression in cultures of E13.5 sympathetic neuroblasts. Neither $\beta$-selective nor $\gamma$-selective retinoids had significant effects on trkA mRNA expression in these cultures $(p>0.2, t$ tests). To investigate further the role of RAR- $\alpha$ in mediating the action of retinoic acid on trkA mRNA expression, we studied the effect of an RAR- $\alpha$-selective antagonist. This antagonist inhibited the effects of retinoic acid on trkA mRNA expression in a dosedependent manner (Fig. 6A). The reduction in trkA mRNA expression by $1 \mathrm{nM}$ retinoic acid was partially inhibited by a tenfold higher level of antagonist and completely inhibited by a 1000 -fold excess of antagonist. The effect of $10 \mathrm{~nm}$ retinoic acid on trkA mRNA expression was significantly inhibited by the antagonist at 100- and 1000-fold higher concentrations, although the level of trkA mRNA did not reach control levels with a 1000 -fold excess of antagonist. On its own, the $\operatorname{RAR} \alpha$ antagonist did not significantly affect trkA mRNA expression in these low density cultures. Taken together, these results suggest that $\operatorname{RAR} \alpha$ receptors are responsible for mediating the effects of retinoic acid on trkA mRNA expression in sympathetic neuroblasts.

The evidence suggesting that retinoic acid acts on cultured sympathetic neuroblasts via RARs- $\alpha$ provided an opportunity to investigate the physiological significance of the effects of retinoic acid on trkA mRNA expression during development. We reasoned that if sympathetic neuroblasts are normally exposed to retinoic acid within the environment of early paravertebral sympathetic ganglia, inhibiting the action of retinoic acid with the RAR- $\alpha$-selective antagonist in ganglion explants should affect trkA mRNA expression. As shown in Figure $6 B$, the RAR- $\alpha$ selective antagonist caused a significant increase in trkA mRNA expression ( $p<0.01, t$ test), whereas retinoic acid prevented the developmental increase in trkA mRNA expression. This effect of the antagonist was observed at a concentration as low as $10 \mathrm{nM}$, suggesting that the level of retinoic acid to which the neuroblasts are exposed in the ganglion is very low. Higher concentrations (up to $1 \mu \mathrm{M}$ ) did not effect a further rise in trkA mRNA (data not shown). These results suggest that retinoic acid normally plays a role in regulating trkA mRNA expression within early sympathetic ganglia. The lack of effect of the RAR- $\alpha$-selective antagonist on trkA mRNA in low-density dissociated cultures of sympathetic neuroblasts (Fig. 6 $\mathrm{A}$ ) is explained by dilution into the culture medium of any endogenous retinoic acid to the point at which it is no longer effective.

\section{Retinoic acid increases the proliferation of sympathetic neuroblasts}

In addition to studying the effect of retinoic acid on neurotrophin receptor expression, we investigated its effect on sympathetic neuroblast proliferation using immunocytochemistry to study BrdU incorporation in vitro. In control cultures (NGF alone), almost $10 \%$ of E13.5 SCG cells incorporated BrdU into their nuclei during a $12 \mathrm{hr}$ incubation period (Fig. 7A). This fell to just $1 \%$ in E15.5 control cultures in accordance with the reduction in the number of proliferating sympathetic neuroblasts in the SCG by this stage. Retinoic acid increased the number of BrdUpositive cells in E13.5, E14.5, and E15.5 cultures (Fig. 7A); the increases at E13.5 and E14.5 were statistically significant $(p<$ $0.005, t$ tests). Similar effects of retinoic acid were observed in E13.5 lumbar sympathetic chain cultures (data not shown). These 
A

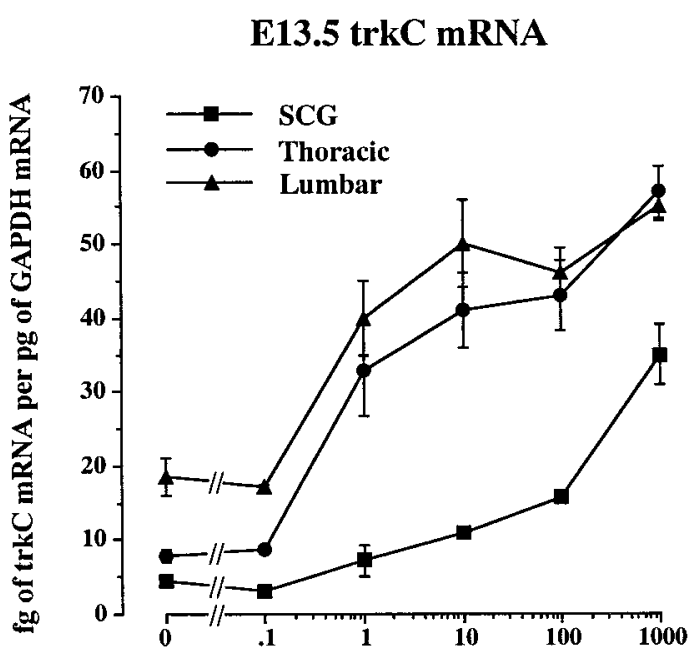

Retinoic acid concentration (nM)
B

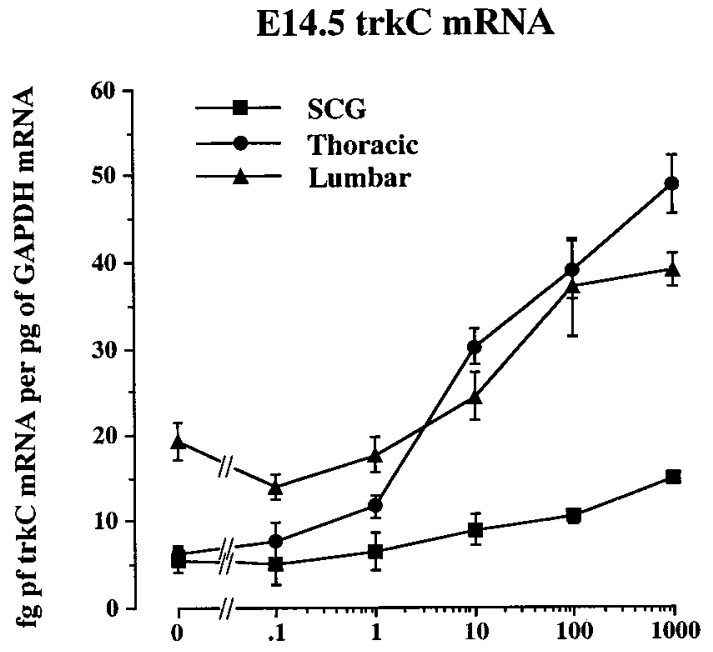

Retinoic acid concentration (nM)
$\mathrm{C}$

\section{E15.5 trkC mRNA}

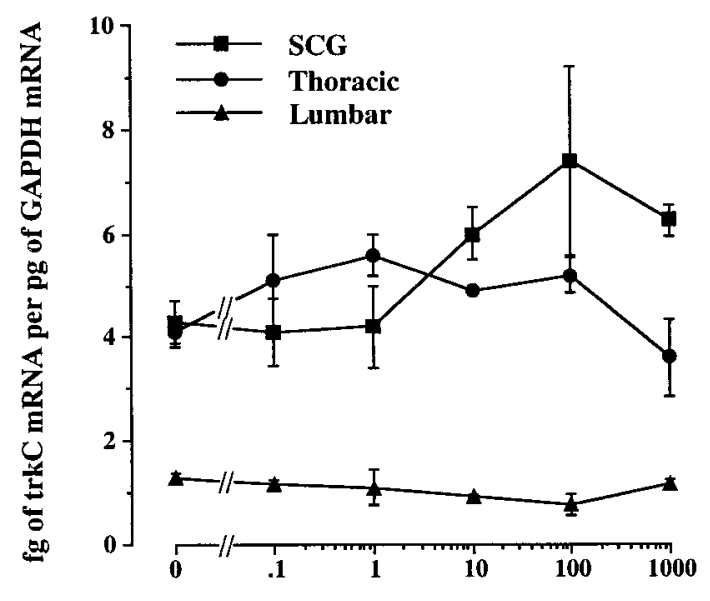

Retinoic acid concentration (nM)

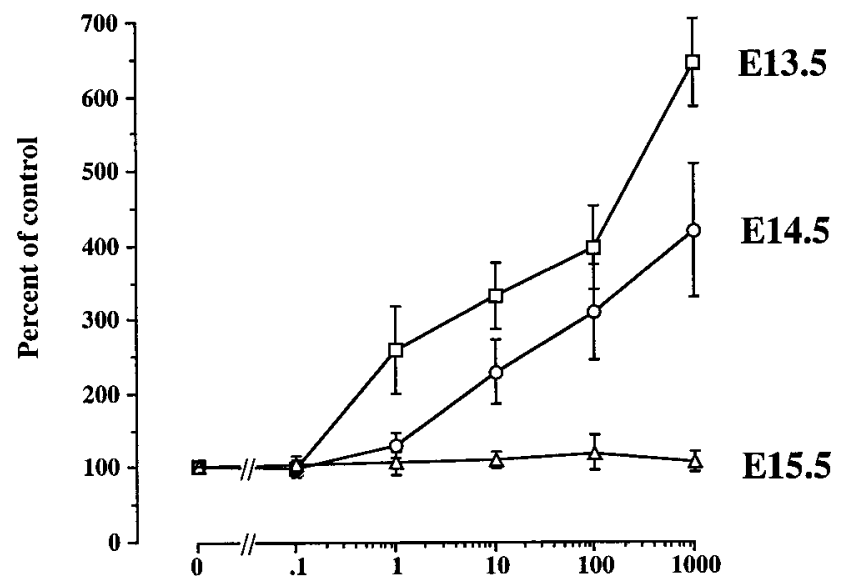

Retinoic acid concentration (nM)

Figure 3. Graphs of the levels of trkC $\mathrm{TK}^{+}$mRNA (relative to GAPDH RNA) in dissociated cultures of E13.5 $(A)$, E14.5 (B), and E15.5 (C) SCG and thoracic and lumbar paravertebral sympathetic ganglia after $48 \mathrm{hr}$ in culture with $5 \mathrm{ng} / \mathrm{ml}$ NGF alone and NGF plus retinoic acid over a range of concentrations. The mean and SE of three to eight separate cultures are shown for each data point. $D$ summarizes the changes with age in the relative level of trkC $\mathrm{TK}^{+}$mRNA in SCG, thoracic, and lumbar cultures containing different concentrations of retinoic acid expressed as a percentage of the level in cultures grown without retinoic acid (derived from data shown in $A-C$ ).

results demonstrate that retinoic acid is capable of increasing sympathetic neuroblast proliferation throughout the developing paravertebral sympathetic chain.

The effect of retinoic acid on neuroblast proliferation differed in several respects from its effect on trkA and trkC mRNA expression. First, the concentration of retinoic acid required to enhance neuroblast proliferation was much higher than that needed to affect trkA and trkC mRNA expression. In E13.5 cultures (Fig. $7 B$ ), significant enhancement of neuroblast proliferation was observed only at retinoic acid concentrations of $10^{-7}$ $\mathrm{M}$ and greater ( $p<0.001, t$ tests), which is 100 - to 1000 -fold higher than the concentrations of retinoic acid required to cause significant changes in trkA and trkC mRNA expression in neuroblast cultures at the same stage of development (Figs. 1A, $3 A$ ). Second, studies using RAR subtype-selective synthetic retinoid agonists (Fig. 7C) suggest that activation of both RAR- $\alpha$ and $\mathrm{RAR}-\beta$ is capable of enhancing neuroblast proliferation. Although only $\alpha$-selective retinoid agonists were effective in reducing trkA mRNA expression (Fig. 5), both $\alpha$-selective and $\beta$-selective retinoids significantly increased proliferation $(p<$ $0.01, t$ tests) (Fig. 7C). Figure 7C also shows that the RAR- $\alpha$ selective antagonist substantially reduced the effect of retinoic 
A

E13.5 p75 mRNA

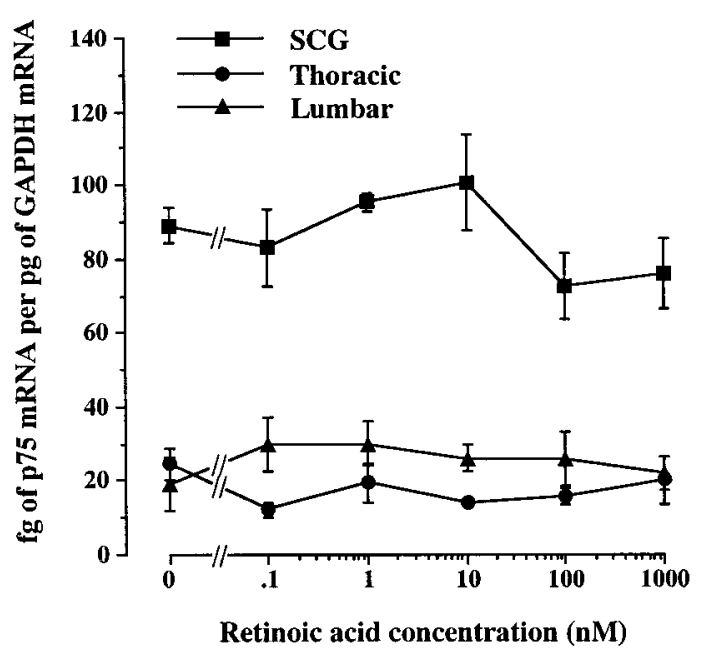

C

E15.5 p75 mRNA

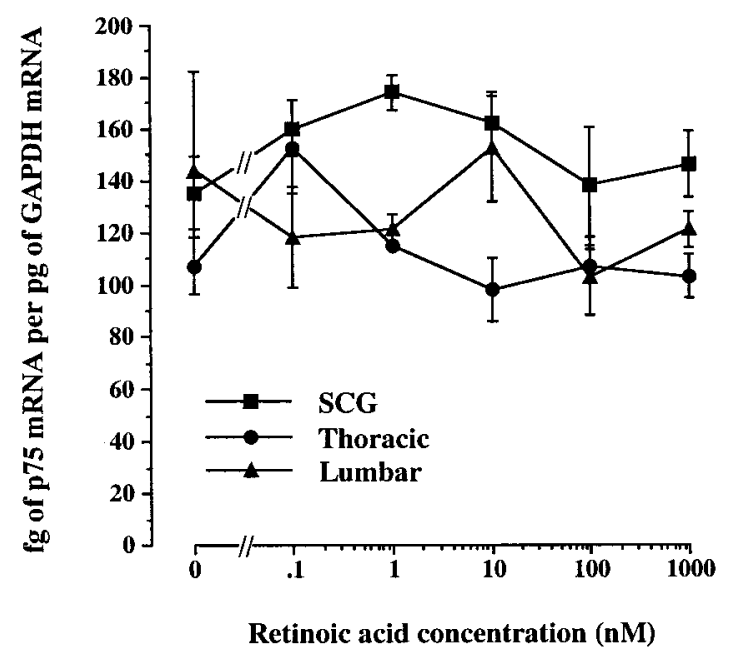

B

\section{E14.5 p75 mRNA}

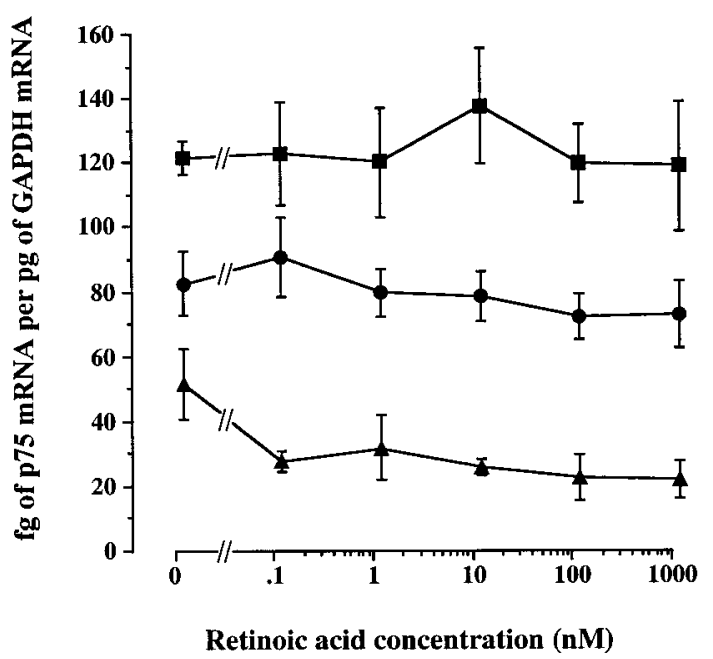

$\mathrm{D}$

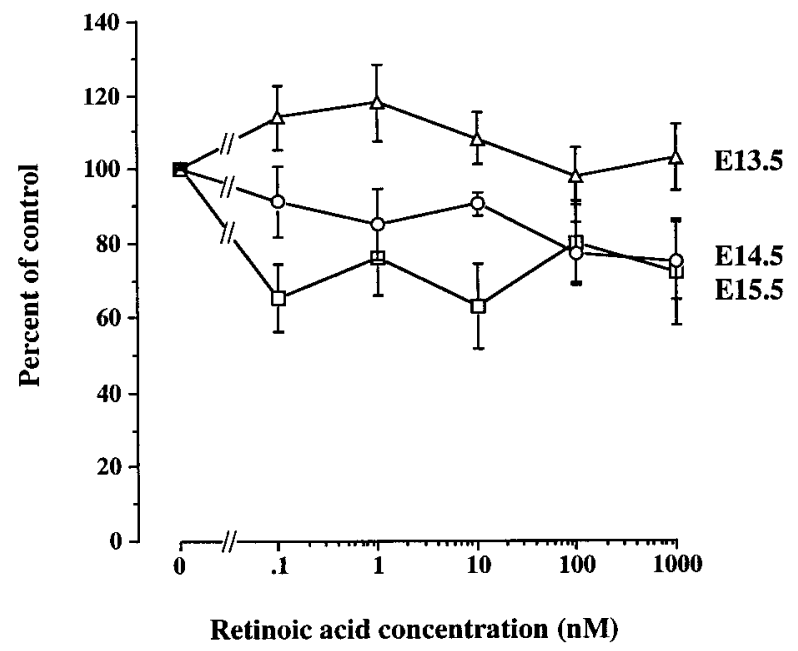

Figure 4. Graphs of the levels of p75 mRNA (relative to GAPDH RNA) in dissociated cultures of E13.5 $(A)$, E14.5 (B), and E15.5 $(C)$ SCG and thoracic and lumbar paravertebral sympathetic ganglia after $48 \mathrm{hr}$ in culture with $5 \mathrm{ng} / \mathrm{ml}$ NGF alone and NGF plus retinoic acid over a range of concentrations. The mean and SE of three to eight separate cultures are shown for each data point. $D$ summarizes the changes with age in the relative level of trkA mRNA in SCG, thoracic, and lumbar cultures containing different concentrations of retinoic acid expressed as a percentage of the level in cultures grown without retinoic acid (derived from data shown in $A-C$ ).

acid on proliferation but did not completely inhibit this effect, suggesting that the effect of retinoic acid on neuroblast proliferation is mediated in part by RAR- $\alpha$. The differences in the concentration ranges over which retinoic acid affects neuroblast proliferation and trk expression and the differences in the synthetic retinoid agonists capable of eliciting these responses suggest that the effect of retinoic acid on Trk mRNA expression is not simply a secondary consequence of a change in neuroblast proliferation.

\section{DISCUSSION}

We have shown that retinoic acid has a marked effect on the expression of trkA and trkC mRNAs in dissociated cultures established from cervical, thoracic, and lumbar levels of the early sympathetic chain of mouse embryos. Although retinoic acid causes a marked, dose-dependent decrease in the level of trkA mRNA, it has the opposite effect on the expression of both $\mathrm{TK}^{+}$ and $\mathrm{TK}^{-}$trkC transcripts. The developmental time course of these actions of retinoic acid suggests that it affects the expression 


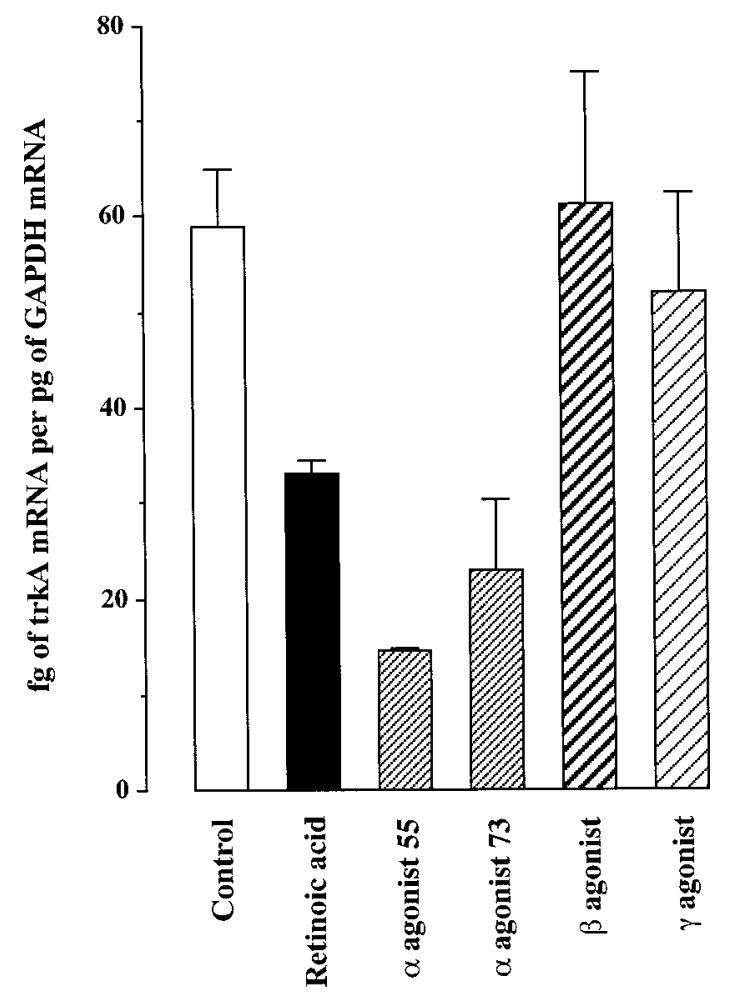

Figure 5. Bar chart of the levels of trkA mRNA (relative to GAPDH RNA) in dissociated cultures of E13.5 SCG neuroblasts grown for $48 \mathrm{hr}$ with retinoic acid, RAR- $\alpha$-selective agonists (Ro 40-6055 and Ro 406973), RAR- $\beta$-selective agonist (Ro 19-0645), and RAR- $\gamma$-selective agonist (Ro 44-7081), each at $10^{-8} \mathrm{M}$. All cultures were also supplemented with $5 \mathrm{ng} / \mathrm{ml} \mathrm{NGF}$ (control cultures received NGF alone). The mean and SE of four separate cultures are shown for each data point.

of neurotrophin receptors mainly, if not exclusively, in sympathetic neuroblasts and not in postmitotic neurons. The effect of retinoic acid on trkA and trkC mRNA is most marked in E13.5 cultures when the sympathetic chain consists predominantly of sympathetic neuroblasts. It becomes less pronounced in E14.5 cultures as many sympathetic neuroblasts in the chain stop dividing and differentiate into postmitotic neurons and is negligible in E15.5 cultures when few sympathetic neuroblasts remain in the chain. Analysis of the changes in trkA mRNA expression in E13.5 neuroblasts with time in culture suggests that retinoic acid inhibits the developmental increase in trkA mRNA that takes place in sympathetic neuroblasts rather than reducing the level of trkA mRNA present at the time of plating.

Our present results are in marked contrast to studies of the effects of retinoic acid on cultured embryonic chicken sympathetic neuroblasts in which it has been shown to induce TrkA expression and the appearance of high-affinity NGF receptors and NGF dependence (Rodriguez-Tebar and Rohrer, 1991; Holst et al., 1995, 1997). Our results also differ from those obtained from chicken sympathetic neuroblasts in which it has been reported that retinoic acid does not affect the expression of trkC mRNA (Holst et al., 1995). It should be pointed out that the differences in the response of chicken and mouse sympathetic neuroblasts to retinoic acid were not attributable to differences in the preparation of retinoic acid or culture media used, because the same media and batches of retinoic acid that induced trkA expression in chicken neuroblasts reduced trkA expression in mouse neuro- blasts (data not shown). Likewise, we observed very similar results when mouse sympathetic neuroblasts were grown in serum containing medium using the same batch of serum that had been used in cultures of chicken sympathetic neuroblasts (data not shown). Although the effect of retinoic acid on trkA mRNA expression was negligible in our cultures of embryonic mouse postmitotic sympathetic neurons, it has been shown that treatment of newborn rat SCG neurons with retinoic acid suppresses trkA mRNA expression and induces trkB mRNA expression (Kobayashi et al., 1994). The physiological relevance of this observation is unclear because sympathetic neurons do not normally express trkB. Retinoic acid, however, has also been shown to influence trkB expression in neuroblastoma cell lines, either increasing (Kaplan et al., 1993) or decreasing it (Ehrhard et al., 1993). Although retinoic acid does not affect p75 mRNA expression in cultures of chicken sympathetic neuroblasts (Holst et al., 1995) and mouse sympathetic neuroblasts (this study), it has been reported to induce p75 expression in neuroblastoma cells (Haskell et al., 1987; Ehrhard et al., 1993; Kogner et al., 1994) and PC12 pheochromocytoma cells (Scheibe and Wagner, 1992). However, the physiological significance of these studies of cells lines for the regulation of p75 expression in normal neuroblasts remains unclear. We have also shown that retinoic acid does not affect the expression of either trkA or p 75 mRNAs by the sensory neurons of the mouse trigeminal ganglion cultured from E11 and E12 embryos (S. Wyatt and A. M. Davies, unpublished observations).

Although there seem to be major differences in the effect of retinoic acid on trkA and trkC expression in sympathetic neuroblasts of developing birds and mammals, in both classes of vertebrates the action of retinoic acid appears to be mediated largely, if not exclusively, by the same kind of retinoic acid receptor. In cultures of chicken sympathetic neuroblasts (Holst et al., 1995) and in our present studies of mouse sympathetic neuroblasts, RAR- $\alpha$ agonists produce the same effect as retinoic acid, and RAR- $\alpha$ antagonists inhibit the action of retinoic acid, suggesting that RARs- $\alpha$ mediate these actions. It is possible, however, that the effect of retinoic acid on neuroblast proliferation may be mediated by both RAR- $\alpha$ and RAR- $\beta$ receptors because RAR- $\alpha$ and RAR- $\beta$ agonists elicit this effect.

Our demonstration that an RAR- $\alpha$ antagonist is able to inhibit the action of exogenous retinoic acid on cultured sympathetic neuroblasts allowed us to test whether endogenous retinoic acid might normally play a role in modulating the expression of trkA mRNA in intact sympathetic ganglia. Our demonstration that an RAR- $\alpha$ antagonist increases the level of trkA mRNA in early sympathetic chain explants is consistent with this idea. The clear increase in trkA mRNA expression in early sympathetic ganglion explants by low levels of antagonist and the ability of higher levels of exogenous retinoic acid to prevent the developmental increase in trkA mRNA expression in these explants indicate that the level of endogenous retinoic acid in the early sympathetic ganglia is low but within the range that can modulate trkA mRNA expression. Perhaps a developmental decrease in the availability of retinoic acid to sympathetic neuroblasts is one of the factors that induces trkA mRNA expression during development. It remains to be ascertained whether retinoic acid is produced within the chain itself or in adjoining tissues.

In addition to retinoic acid, several other factors have been proposed to play a role in regulating neurotrophin receptor 


\section{Dissociated SCG neurons}

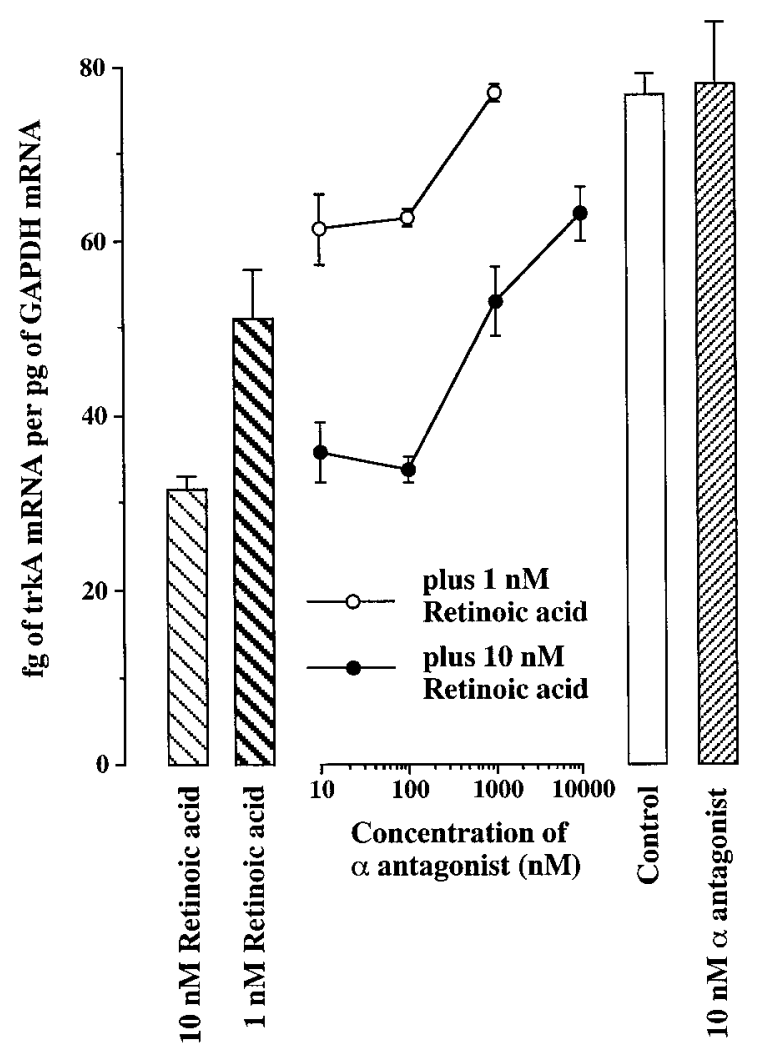

\section{SCG explants}

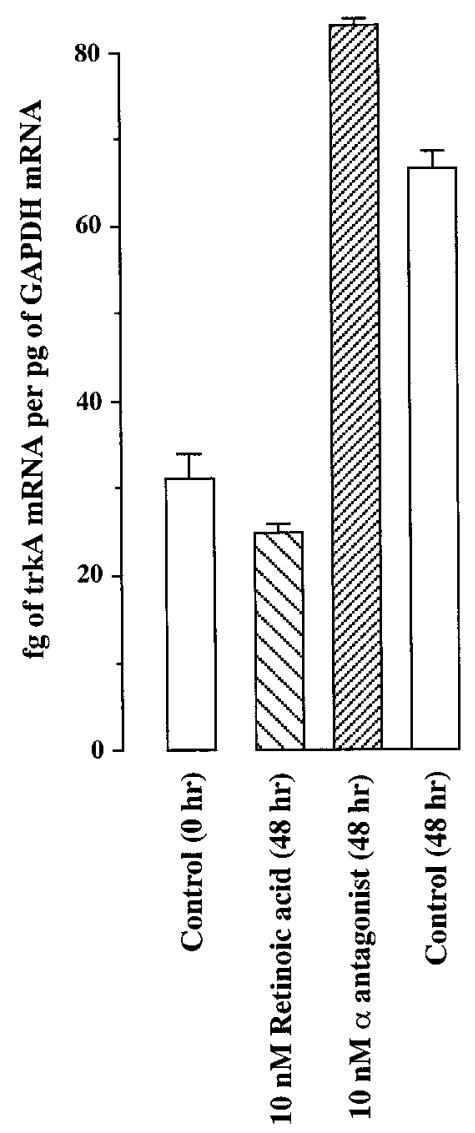

Figure 6. A, Bar chart and graph of the levels of trkA mRNA (relative to GAPDH RNA) in dissociated cultures of E13.5 SCG neuroblasts grown for 48 hr with retinoic acid at 1 and $10 \mathrm{~nm}$ alone or together with an RAR- $\alpha$ selective antagonist (Ro 41-5253) over a range of concentrations. The level of trkA mRNA in cultures containing the $\mathrm{RAR}-\alpha$-selective antagonist alone is also shown. All cultures were also supplemented with $5 \mathrm{ng} / \mathrm{ml} \mathrm{NGF}$ (control cultures received NGF alone). $B$, Bar chart of the levels of trkA mRNA (relative to GAPDH RNA) in explant cultures of E13.5 SCG at the time of plating (Control, $0 \mathrm{hr}$ ) and grown for $48 \mathrm{hr}$ with retinoic acid and the RAR- $\alpha$ selective antagonist. All cultures were also supplemented with $5 \mathrm{ng} / \mathrm{ml}$ NGF (control cultures received NGF alone). The mean and SE of four separate cultures are shown for each data point. expression in sympathetic neuroblasts. The observation that depolarizing levels of $\mathrm{KCl}$ induce trk $A$ mRNA expression in $\mathrm{MAH}$ cells, a retrovirally immortalized sympathoadrenal precursor cell line, has led to the proposal that depolarization induces TrkA expression in sympathetic neuroblasts (Birren et al., 1992). However, in primary cultures of sympathetic neuroblasts and neurons from the embryonic mouse SCG, depolarizing levels of $\mathrm{KCl}$ do not increase trk $A$ mRNA expression before, during, or after the onset of NGF dependence, suggesting that depolarization is not required for TrkA expression in normal sympathetic neurons during development (Wyatt and Davies, 1995). Because high concentrations of NT3 increase trkA mRNA expression in sympathetic neuroblast cultures, it has been concluded that NT3 plays a key role in inducing TrkA expression in these cells during development (Verdi and Anderson, 1994; Verdi et al., 1996). However, measurements of $\operatorname{trk} A$ mRNA in the SCG and thoracic ganglia of $N T 3^{-1-}$ mice have shown that the levels rise normally during the stage of development when the neurons of these ganglia acquire responsiveness to $\mathrm{NGF}$, and by E16, when the majority of neurons have become responsive to NGF, the levels of trkA mRNA in $N T 3^{-1-}$ and wild-type embryos are not significantly different (Wyatt et al., 1997).

In addition to its effect on trkA and trkC expression, we have also shown that retinoic acid increases the number of sympathetic neuroblasts incorporating BrdU into their nuclei in culture, raising the possibility that retinoic acid may also play a role in regulating sympathetic neuroblast proliferation. It is interesting that the combined effects of retinoic acid on mouse sympathetic neuroblasts serve to slow down the progression of developmental changes in these cells. During the early stages of sympathetic neuroblast development, the level of trkA mRNA increases, the level of trkC mRNA decreases, and the neuroblasts stop dividing. Exogenous retinoic acid counters these changes: it inhibits the developmental increase in trkA mRNA, it increases trkC mRNA expression, and it sustains proliferation. Retinoic acid does not affect p75 mRNA expression in sympathetic neuroblasts, which express fairly constant levels of this mRNA throughout their development. Only after E17 do the levels of p75 mRNA and protein rise markedly in sympathetic neurons to approach the level of trkA mRNA in the postnatal period (Horton et al., 1997; Wyatt et al., 1997). Because of the differences in the concentration ranges over which retinoic acid affects trk expression and neuroblast proliferation and differences in the kinds of RAR agonists that mimic these effects, it is unlikely that the effects of retinoic acid on trk expression are secondary to changes in neuroblast proliferation. Rather, it seems that retinoic acid affects both aspects of neuroblast development independently. In common with its effect on influencing the differentiation of many cell types in the embryo, our results suggest that retinoic acid plays a role in regulating the differentiation and development of sympathetic neuroblasts in the mouse embryo. 
A

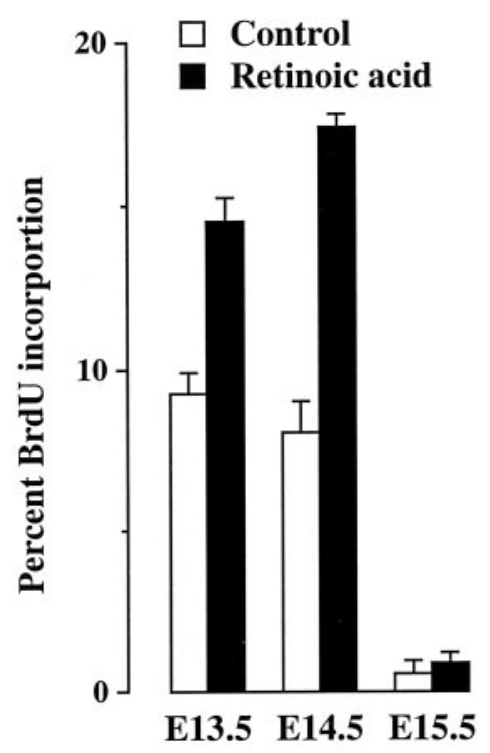

B

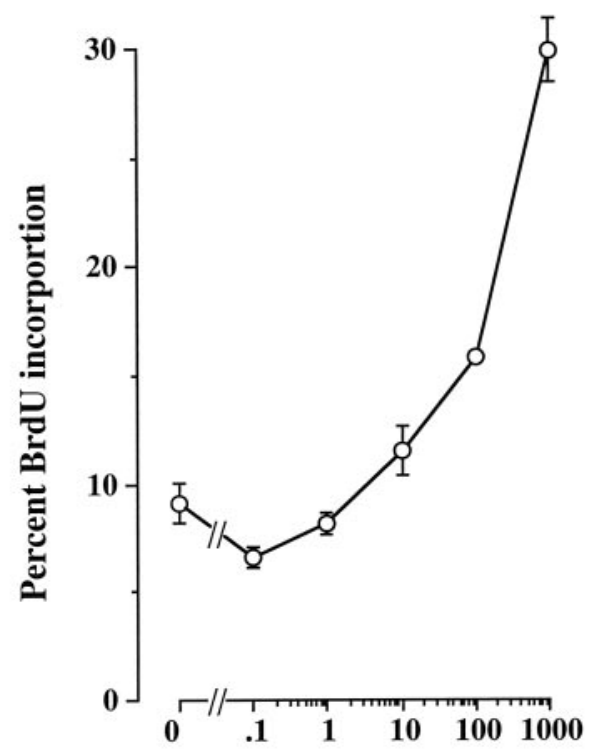

Retinoic acid concentration (nM)

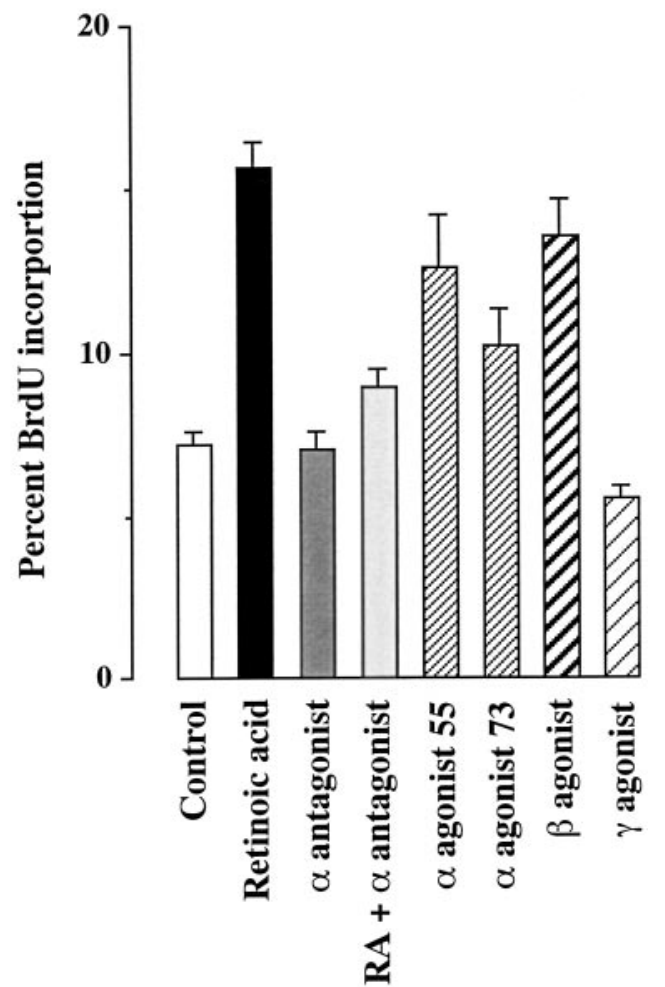

Figure 7. A, Bar chart showing the percentage of cells in dissociated cultures of E13.5, E14.5, and E15.5 SCG that incorporated BrdU during a 12 hr incubation period in control cultures and cultures containing $10^{-7} \mathrm{M}$ retinoic acid. $B$, Graph showing the percentage of cells in dissociated cultures of E13.5 SCG that incorporated BrdU during a $12 \mathrm{hr}$ incubation period in control cultures and cultures containing retinoic acid over a range of concentrations. $C$, Bar chart showing the percentage of cells in dissociated cultures of E14.5 SCG that incorporated BrdU during a 12 hr incubation period in control cultures and cultures containing retinoic acid, RAR- $\alpha$-selective antagonist (Ro 41-5253), RAR- $\alpha$-selective agonists (Ro 40-6055 and Ro 40-6973), RAR- $\beta$-selective agonist (Ro 19-0645), and RAR- $\gamma$-selective agonist (Ro 44-7081), each at $10^{-7} \mathrm{M}$, except the antagonist, which was at a concentration of $10^{-6} \mathrm{M}$. The mean and SE of three separate cultures are shown for each data point.

\section{REFERENCES}

Anderson DJ, Axel R (1986) A bipotential neuroendocrine precursor whose choice of cell fate is determined by NGF and glucocorticoids. Cell 47:1079-1090.

Apfel C, Bauer F, Crettaz M, Forni L, Kamber M, Kaufmann F, LeMotte P, Pirson W, Klaus M (1992) A retinoic acid receptor alpha antagonist selectively counteracts retinoic acid effects. Proc Natl Acad Sci USA 89:7129-7133.

Armstrong RB, Ashenfelder KO, Eckhoff C, Levin AA, Shapiro SS (1994) General and reproductive toxicology of retinoids. In: The retinoids (Sporn MB, Roberts AB, Goodman DS, eds), pp 545-572. New York: Raven.

Bamji SX, Majdan M, Pozniak CD, Belliveau DJ, Aloyz R, Kohn J, Causing CG, Miller FD (1998) The p75 neurotrophin receptor mediates neuronal apoptosis and is essential for naturally occurring sympathetic neuronal death. J Cell Biol 140:911-923.

Barbacid M (1994) The Trk family of neurotrophin receptors. J Neurobiol 25:1386-1403.

Barrett GL, Bartlett PF (1994) The p75 nerve growth factor receptor mediates survival or death depending on the stage of sensory neuron development. Proc Natl Acad Sci USA 91:6501-6505.

Birren SJ, Verdi JM, Anderson DJ (1992) Membrane depolarization induces p140trk and NGF responsiveness, but not p75LNGFR, in MAH cells. Science 257:395-397.

Birren SJ, Lo L, Anderson DJ (1993) Sympathetic neuroblasts undergo a developmental switch in trophic dependence. Development 119:597-610.

Bothwell M (1995) Functional interactions of neurotrophins and neurotrophin receptors. Annu Rev Neurosci 18:223-253.
Buchman VL, Davies AM (1993) Different neurotrophins are expressed and act in a developmental sequence to promote the survival of embryonic sensory neurons. Development 118:989-1001.

Casaccia-Bonnefil P, Carter BD, Dobrowsky RT, Chao MV (1996) Death of oligodendrocytes mediated by the interaction of nerve growth factor with its receptor p75. Nature 383:716-719.

Cohen AM (1974) DNA synthesis and cell division in differentiating avian adrenergic neuroblasts. In: Dynamics of degeneration and growth in neurons, Wenner-Gren Center International Symposium Series (Fuxe K, Olson L, Zotterman Y, eds), pp 359-370. Oxford: Pergamon.

Coughlin MD,Collins MB (1985) Nerve growth factor-independent development of embryonic mouse sympathetic neurons in dissociated cell culture. Dev Biol 110:392-401.

Crowley C, Spencer SD, Nishimura MC, Chen KS, Pitts-Meek S, Armanini MP, Ling LH, McMahon SB, Shelton DL, Levinson AD, Phillips HS (1994) Mice lacking nerve growth factor display perinatal loss of sensory and sympathetic neurons yet develop basal forebrain cholinergic neurons. Cell 76:1001-1011.

Davey F, Davies AM (1998) TrkB signalling inhibits p75-mediated apoptosis induced by NGF in embryonic proprioceptive neurons. Curr Biol 8:915-918.

Davies AM (1994) Role of neurotrophins in the developing nervous system. J Neurobiol 25:1334-1348.

Davies AM, Lumsden AGS (1984) Relation of target encounter and neuronal death to nerve growth factor responsiveness in the developing mouse trigeminal ganglion. J Comp Neurol 223:124-137.

Davies AM, Lee KF, Jaenisch R (1993) p75-deficient trigeminal sensory neurons have an altered response to NGF but not to other neurotrophins. Neuron 11:565-574. 
Dechant G, Rodriguez TA, Kolbeck R, Barde YA (1993) Specific highaffinity receptors for neurotrophin-3 on sympathetic neurons. J Neurosci 13:2610-2616.

DiCicco-Bloom E, Black IB (1988) Insulin growth factors regulate the mitotic cycle in cultured rat sympathetic neuroblasts. Proc Natl Acad Sci USA 85:4066-4070.

DiCicco-Bloom E, Townes-Anderson E, Black IB (1990) Neuroblast mitosis in dissociated culture: regulation and relationship to differentiation. J Cell Biol 110:2073-2086.

DiCicco-Bloom E, Friedman WJ, Black IB (1993) NT-3 stimulates sympathetic neuroblast proliferation by promoting precursor cell survival. Neuron 11:1101-1111.

Durbec PL, Larsson-Blomberg LB, Schuchardt A, Costantini F, Pachnis V (1996) Common origin and developmental dependence on c-ret of subsets of enteric and sympathetic neuroblasts. Development 122:349-358.

Ehrhard PB, Ganter U, Schmutz B, Bauer J, Otten U (1993) Expression of low-affinity NGF receptor and trkB mRNA in human SH-SY5Y neuroblastoma cells. FEBS Lett 330:287-292.

Ernsberger U, Rohrer H (1988) Neuronal precursor cells in chick dorsal root ganglia: differentiation and survival in vitro. Dev Biol $126: 420-432$

Ernsberger U, Edgar D, Rohrer H (1989) The survival of early chick sympathetic neurons in vitro is dependent on a suitable substrate but independent of NGF. Dev Biol 135:250-262.

Farinas I, Yoshida CK, Backus C, Reichardt LF (1996) Lack of neurotrophin-3 results in death of spinal sensory neurons and premature differentiation of their precursors. Neuron 17:1065-1078.

Frade JM, Rodriguez-Tebar A, Barde YA (1996) Induction of cell death by endogenous nerve growth factor through its p75 receptor. Nature 383:166-168.

Haskell BE, Stach RW, Werrbach-Perez K, Perez-Polo JR (1987) Effect of retinoic acid on nerve growth factor receptors. Cell Tissue Res 247:67-73.

Holst A, Rodriguez-Tebar A, Michaille JJ, Dhouailly D, Backstrom A, Ebendal T, Rohrer H (1995) Retinoic acid-mediated increase in TrkA expression is sufficient to elicit NGF-dependent survival of sympathetic neurons. Mol Cell Neurosci 6:185-198.

Holst A, Lefcort F, Rohrer H (1997) TrkA expression levels of sympathetic neurons correlate with NGF-dependent survival during development and after treatment with retinoic acid. Eur J Neurosci 9:2169-2177.

Horton AR, Laramee G, Wyatt S, Shih A, Winslow J, Davies AM (1997) NGF binding to p75 enhances the sensitivity of sensory and sympathetic neurons to NGF at different stages of development. Mol Cell Neurosci 10:162-172.

Johnson EM, Gorin PD, Brandeis LD, Pearson J (1980) Dorsal root ganglion neurons are destroyed by in utero exposure to maternal antibody to nerve growth factor. Science 210:916-918.

Kaplan DR, Matsumoto K, Lucarelli E, Thiele CJ (1993) Induction of TrkB by retinoic acid mediates biologic responsiveness to BDNF and differentiation of human neuroblastoma cells. Eukaryotic Signal Transduction Group. Neuron 11:321-331.

Kobayashi M, Kurihara K, Matsuoka I (1994) Retinoic acid induces BDNF responsiveness of sympathetic neurons by alteration of Trk neurotrophin receptor expression. FEBS Lett 356:60-65.

Kogner P, Barbany G, Persson H, Soderhall S, Ahstrom L, Bjork O (1994) Expression of nerve growth factor receptor mRNAs and clinical response to retinoic acid in neuroblastoma. Prog Clin Biol Res 385:147-153.

Lamballe F, Tapley P, Barbacid M (1993) trkC encodes multiple neurotrophin-3 receptors with distinct biological properties and substrate specificities. EMBO J 12:3083-3094.

Lee KF, Davies AM, Jaenisch R (1994) p75-deficient embryonic dorsal root sensory and neonatal sympathetic neurons display a decreased sensitivity to NGF. Development 120:1027-1033.

Leid M, Kastner P, Chambon P (1992) Multiplicity generates diversity in the retinoic acid signalling pathways. Trends Biochem Sci 17:427-433.

Levi-Montalcini R (1987) The nerve growth factor 35 years later. Science 237:1154-1162.

Lewin GR, Barde YA (1996) The physiology of neurotrophins. Annu Rev Neurosci 19:289-317.

Maina F, Hilton MC, Andres R, Wyatt S, Klein R, Davies AM (1998) Multiple roles for hepatocyte growth factor in sympathetic neuron development. Neuron 20:835-846.

Moore MW, Klein RD, Farinas I, Sauer H, Armanini M, Phillips H, Reicherdt LF, Ryan AM, Carver-Moore K, Rosenthal A (1996) Re- nal and neuronal abnormalities in mice lacking GDNF. Nature 382:76-79.

Ninkina N, Adu J, Fischer A, Pinon LG, Buchman VL, Davies AM (1996) Expression and function of TrkB variants in developing sensory neurons. EMBO J 15:6385-6393.

Paul G, Davies AM (1995) Trigeminal sensory neurons require extrinsic signals to switch neurotrophin dependence during the early stages of target field innervation. Dev Biol 171:590-605.

Piñón LGP, Minichiello L, Klein R, Davies AM (1996) Timing of neuronal death in $\operatorname{trk} A, \operatorname{trk} B$ and $\operatorname{trk} C$ mutant embryos reveals developmental changes in sensory neuron dependence on Trk signalling. Development 122:3255-3261.

Rabizadeh S, Oh J, Zhong LT, Yang J, Bitler CM, Butcher LL, Bredesen DE (1993) Induction of apoptosis by the low-affinity NGF receptor. Science 261:345-348.

Robinson M, Adu J, Davies AM (1996) Timing and regulation of $t r k B$ and $B D N F$ mRNA expression in placode-derived sensory neurons and their targets. Eur J Neurosci 8:2399-2406.

Rodriguez-Tebar A, Rohrer H (1991) Retinoic acid induces NGFdependent survival response and high-affinity NGF receptors in immature chick sympathetic neurons. Development 112:813-820.

Rohrer H, Thoenen H (1987) Relationship between differentiation and terminal mitosis: chick sensory and ciliary neurons differentiate after terminal mitosis of precursor cells, whereas sympathetic neurons continue to divide after differentiation. J Neurosci 7:3739-3748.

Rothman TP, Gershon MD, Holtzer H (1978) The relationship of cell division to the acquisition of adrenergic characteristics by developing sympathetic ganglion cell precursors. Dev Biol 65:322-341.

Rothman TP, Specht LA, Gershon MD, John TH, Teitelman G, Pickel VM, Reis DJ (1980) Catecholamine biosynthetic enzymes are expressed in replicating cells of the peripheral but not the central nervous system. Proc Natl Acad Sci USA 77:6221-6225.

Ryden M, Murray-Rust J, Glass D, Ilag LL, Trupp M, Yancopoulos GD, McDonald NQ, Ibanez CF (1995) Functional analysis of mutant neurotrophins deficient in low-affinity binding reveals a role for p75LNGFR in NT-4 signalling. EMBO J 14:1979-1990.

Scheibe RJ, Wagner JA (1992) Retinoic acid regulates both expression of the nerve growth factor receptor and sensitivity to nerve growth factor. J Biol Chem 267:17611-17616.

Smeyne RJ, Klein R, Schnapp A, Long LK, Bryant S, Lewin A, Lira SA, Barbacid M (1994) Severe sensory and sympathetic neuropathies in mice carrying a disrupted Trk/NGF receptor gene. Nature 368:246-249.

Tsoulfas P, Soppet D, Escandon E, Tessarollo L, Mendoza RJ, Rosenthal A, Nikolics K, Parada LF (1993) The rat trkC locus encodes multiple neurogenic receptors that exhibit differential response to neurotrophin-3 in PC12 cells. Neuron 10:975-990.

Valenzuela DM, Maisonpierre PC, Glass DJ, Rojas E, Nunez L, Kong Y, Gies DR, Stitt TN, Ip NY, Yancopoulos GD (1993) Alternative forms of rat TrkC with different functional capabilities. Neuron 10:963-974.

Van der Zee CE, Ross GM, Riopelle RJ, Hagg T (1996) Survival of cholinergic forebrain neurons in developing p75NGFR-deficient mice. Science 274:1729-1732.

Verdi JM, Anderson DJ (1994) Neurotrophins regulate sequential changes in neurotrophin receptor expression by sympathetic neuroblasts. Neuron 13:1359-1372.

Verdi JM, Groves AK, Farinas I, Jones K, Marchionni M, Reichardt LF, Anderson DJ (1996) A reciprocal cell-cell interaction mediated by NT-3 and neuregulins controls the early survival and development of sympathetic neuroblasts. Neuron 16:515-527.

Vogel KS, Davies AM (1991) The duration of neurotrophic factor independence in early sensory neurons is matched to the time course of target field innervation. Neuron 7:819-830.

Wilkinson GA, Fariñas I, Backus C, Yoshida CK, Reichardt LF (1996) Neurotrophin-3 is a survival factor in vivo for early mouse trigeminal neurons. J Neurosci 16:7661-7669.

Wyatt S, Davies AM (1993) Regulation of expression of mRNAs encoding the nerve growth factor receptors p75 and trkA in developing sensory neurons. Development 119:635-648.

Wyatt S, Davies AM (1995) Regulation of nerve growth factor receptor gene expression in sympathetic neurons during development. J Cell Biol 130:1435-1446.

Wyatt S, Piñón LGP, Ernfors P, Davies AM (1997) Sympathetic neuron survival and TrkA expression in NT3-deficient mouse embryos. EMBO J 16:3115-3123. 